SUSTAINABLE FORESTRY

COLLECTION 79-80, 2019
ODRŽIVO ŠUMARSTVO

ZBORNIK RADOVA 79-80, 2019

UDK UDK $630 * 585$

UDK 528.88:630

Professional paper

\title{
APPLICATION OF SMALL UNAMANNED AERIAL SYSTEMS IN LOGISTICS AND PLANNING
}

\author{
Nenad ŠURJANAC ${ }^{l}$, Natalija MOMIROVIĆl ${ }^{l}$ Marija MILOSAVLJEVIĆ , $^{\prime}$ \\ Sonja BRAUNOVIĆ ${ }^{l}$, Milan KABILJO ${ }^{l}$
}

\begin{abstract}
The application of modern technologies makes it easy to collect, process, present, and apply data for logistics in hard to reach areas. Proper delivery of equipment, personnel, and materials directly affects the quality of work. The need for precise and real information about the condition of the terrain and the conditions of the environment has always existed since this knowledge enables proper planning, forecasting and task performing in the field. Improvement in the digital industry enables fast and easy transfer of unchanged digital data from the field to the information processing centers, which consequently improves decision making and planning processes. New workflows made proper logistics even more important because it increased the precision of field work and better anticipation of previously unforeseen circumstances. Work on hard to reach areas, with large slopes, non-existent and/or non-persistent infrastructure, and different degree of vegetation coverage requires precise planning and organization of works, in order to minimize the number of unforeseen situations and make the most expeditious workflows. This paper presents the practical application of small unmanned aerial systems for collecting a large amount of data in a short time, the processing of the data, and the production of relevant information for decision making. There are two most important aspects of this paper. First one is fast, easy, safe and precise collection of large amounts of data which is an alternative to the traditional methods. The second is computer data processing, which enables a fast and automatic transformation of raw data into relevant information in digital formats that are suitable for further processing and easily accessible to decision makers. This work shows that it is possible to record quickly and in detail a large area, and obtain real, current, accurate and high-fidelity information about each
\end{abstract}

\footnotetext{
${ }^{1}$ MSc Nenad Šurjanac, MSc Natalija Momirović, MSc Marija Milosavljević, Dr Sonja Braunović, MSc Milan Kabiljo, Institute of Forestry, Kneza Višeslava 3, 11030 Belgrade, Serbia.

Author for correspondence: Nenad Šurjanac, Institute of Forestry, Kneza Višeslava 3, 11030 Belgrade, Serbia, +381603346230, e-mail: surjanacn@gmail.com
} 
point of terrain, with high precision and reliability.

Keywords: unmanned aerial systems, Agisoft Metashape, logistics, terrain mapping, terrain modeling

\section{PRIMENA MALIH BESPILOTNIH SISTEMA U LOGISTICI I PLANIRANJU}

Izvod: Primena modernih tehnologija omogućava lako prikupljanje, obradu, prezentovanje i primenu podataka u logistici u teško pristupačnim terenima. Adekvatno dostavljanje opreme, ljudstva i materijala direktno utiče na kvalitet radova. Potreba za preciznim i realnim informacijama u vezi sa uslovima terena $i$ okoline je oduvek postojala, jer ovo znanje omogućava pravilno planiranje, predviđanje i izvođenje zadataka na terenu. Napredak $u$ digitalnoj industriji omogućava brz i lak prenos neizmenjenih podataka sa terena do centara za obradu podataka, što dalje unapređuje proces donošenja odluka $i$ planiranje. Nove procedure rada su doprinele značaju logistike jer je povećana preciznost izvođenja radova kao i predviđanje do sada nepredvidivih okolnosti. Velika preciznost planiranja je neophodna kada se radi na nepristupačnim terenima sa velikim nagibima $i$ nepostojanom infrastrukturom $i$ sa različitom pokrivenošću vegetacijom. Time se smanjuje broj nepredvidenih situacija na minimum i ubrzava proces rada. $U$ radu je prikazana praktična primena malih bespilotnih letelica za brzo prikupljanje velike količine podataka, zatim obradu podataka, i stvaranje relevantnih informacija potrebnih za donošenje odluka. Ovaj rad ima dva bitna aspekta. Prvi je brzo, lako, bezbedno, i precizno prikupljanje velike količine podataka u poređenju sa tradicionalnim metodama. Drugi aspekt je kompjuterska obrada podataka koja omogućava brzu i automatsku transformaciju sirovih podataka u relevantne informacije, koje su pogodne za dalju obradu i lako dostupne profesionalcima odgovornim za donošenje odluka. Ovaj rad prikazuje da je moguće brzo i detaljno snimiti veliku površinu, $i$ dobiti tačne $i$ veoma pouzdane informacije o svakom delu terena sa visokom preciznošću. podataka

Ključne reči: Mali bespilotni sistemi, agisoft metashape, logistika, prikupljanje

\section{INTRODUCTION}

Any kind of field work requires careful preparation and efficient workflow and organization. Transportation, delivering and support for personnel and equipment are the first elements to be considered in terms of fieldwork and operations. Since the purpose of logistics is planning and managing of the flow of the equipment and people, the accurate information about the environment and essentials for successful operations and task execution are needed. With a sufficient amount of precise information, we can plan, predict, and foresee the best and the most efficient workflow. Acquiring the information would be the first issue to address especially when entire work has to be done in remote areas. These hard-toreach areas are especially affected with lack of actual and real-time information which is needed for the decision-making process and proper workflow planning and scheduling. If logistics suffer from GIGO (Garbage in - Garbage out) syndrome, it cannot be expected for the workflow to fulfill high standards of execution.

In order to cover large areas in a fast manner, we opted for aerial 
photography as it was still the most widely used form of aerial imaging (Campbell and Wynne, 2011) and the cost-effective form of remote sensing (2015). Ever since World War I reconnaissance, aerial photography has been improving and delivering more information through the processes of photogrammetry and feature extraction. Images are very versatile and they carry a lot of valuable spatial and temporal information about our environment (Campbell and Wynne, 2011). The additional reasons for choosing small Unmanned Aerial Systems were the high versatility of drones and high level of detail which was possible to get from onboard visual sensor.

The especially important aspect of logistics is the "greenness". The logistic is a heart of transportation of manpower and equipment. If the costs of transportation are being cut, and better utilization of vehicles and distribution has been implemented, we can talk about green logistics (Rodrigue et al., 2017).

In addition to the reduced costs, the utilization of the small Unmanned aerial vehicle is a silent and non-invasive way to gather data, without disturbing the environment. Also, airborne vehicles can cover a large area and focus resources on the current situations (2004).

Unmanned aerial vehicle (UAV) or more commonly known as a drone is remotely operated aircraft without a pilot on board. The ease of use and fast deployment have moved drones from military use into civilian in the past few decades. Moreover, the use of small UAVs has been widely exploited in engineering and scientific use. The whole set of equipment - aerial vehicle/platform, a video sensor, and ground control station is represented by the term small Unmanned Aerial System (sUAS). Since the most of the civilian applications include drones that weigh less than $50 \mathrm{~kg}$ (very often just a few kilograms) these are considered as a small sUAS. Basic classification of sUAS is on fixed-wing (they resemble an airplane) and multicopter (with 3 or more propellers). Each of the classes has certain advantages and purposes, but those comparations are beyond the scope of this paper, and they are not discussed here.

The aim of this paper is to present and examine the possibilities and opportunities of the application of sUAS and feature extraction software for the purpose of the increase of the amount and improving the precision of the information needed in logistics. The multicopters UAS was found to be the most suitable one for this study.

In this paper, it was examined what kind of information can be produced from the data collected in the field. These raw data will be processed through the various algorithms in order to produce information which will be further used for planning and decision making. This information would affect both human stakeholders (decision makers, employees, investors, end-users, etc.) and natural environment as the non-human stakeholder. The main idea is to give opportunity to decision makers to make the right decisions based on the information unspoiled and unchanged by subjective judgment of the person collecting the data; and at the same time to give more space to manipulate and experiment with different approaches to processing of the data in order to get the most useful information, and thus the more optimized workflow. 


\section{MATHERIAL AND METHODS}

In order to examine the possibility of sUAS and associated technologies, the study area that would be very demanding for traditional methods of terrain analyses work was selected. Also, this area would be a good representative of terrain which demands good and precise information prior to the start of field work.

The area chosen for this study is situated in Bosnia and Herzegovina, Republika Srpska entity, $4 \mathrm{~km}$ southwest from the town of Nevesinje, and it covers $1.6 \mathrm{~km}^{2}$ (Picture 1). The actual coordinates of the terrain are 43.219497, 18.0509090 SE, and 43.238675, 18.0709605 NW, in WGS84 (EPSG: 4326) projection. This area is dominated with typical karst relief. It consists of several hills, high and low vegetation, dirt roads, and several fenced agricultural fields (tillage and pastures).

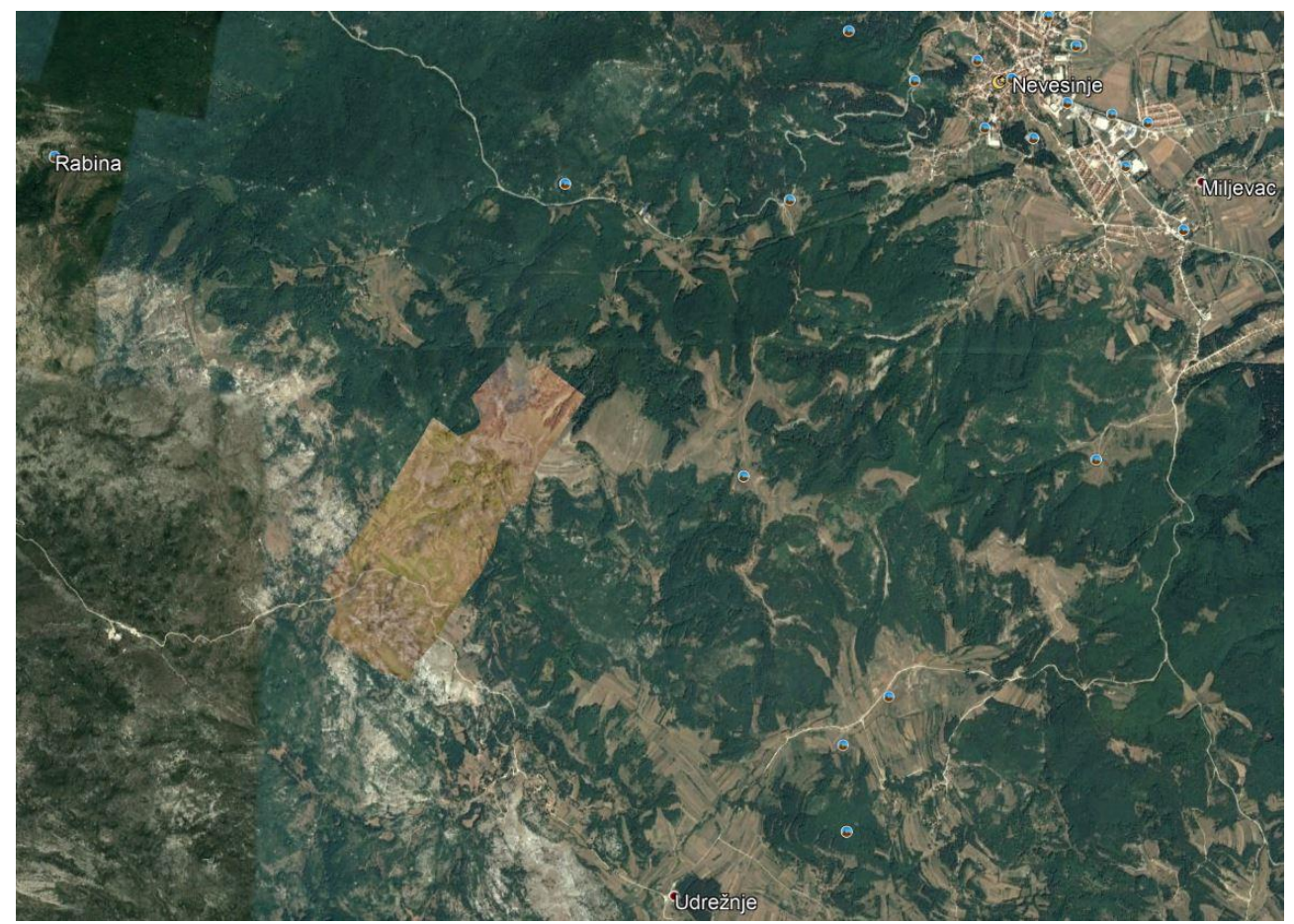

Picture 1. Study area

The equipment used for this was DJI Phantom 4. This sUAS weighs only $1.4 \mathrm{~kg}$ and has the ability to sustain wind up to $80 \mathrm{~km} / \mathrm{h}$. The aircraft has a GPS/GLONASS navigational system for accurate positioning and it also allows its onboard CMOS sensor to capture $20 \mathrm{Mpix}$ geotagged still images. In order to capture all images in nadir setting the sensor/camera was mounted on 3-axis gimbal. Easy deployment and small visual and audio footprint made this aircraft ideal for the purpose of aerial photography. This electrically powered UAS can cover up to 25 ha in a single flight, with every flight lasting about 25 minutes.

The flight routes were designed before the launch and those were performed through an onboard computer in auto-pilot mode. The flight software of 
choice was Drone Deploy. The field coverage was performed with $80 \%$ of the front, and $80 \%$ of the side overlap between the neighboring images. The chosen altitude was $100 \mathrm{~m}$ above ground level from the take-off point. This allowed high detail on every image, plus it proved to be a safe altitude when considering the variety of terrain elevation and vegetation height.

All images were processed in professional photogrammetry software Agisoft Metashape. The hardware used for this purpose consists of i7 8700k 4.9 GHz CPU, RTX 2070 GPU, 64GB RAM and both solid-state and rotary hard drives for processing and storage.

The second part of processing took place in Trimble eCognition Developer, and ArcMap software which allows application of various algorithms, classification and feature extraction. The software provided more information on the area of interest, in addition to the models, features, and exports from Agisoft Metashape.

The first product in Agisoft was Dense Point Cloud. Each point in the cloud had its X, Y, and Z coordinates. From point cloud, the Digital Elevation Model (DEM) and Digital Surface Model (DSM) were created. The information from the DEM combined with the source digital images produced the orthomosaic with spatial information of the terrain.

Accuracy check and improvement and transformation of coordinate system projection were achieved through the use of Ground Control Points. These high accuracy points were measured with high-precision GPS RTK surveying equipment before the flight and those were used during the processing to increase the precision of the terrain model, which consequently improved the accuracy of the DEM, DSM, and orthomosaic.

Agisoft Metashape was used for identification, drawing, and measurement of profiles, slopes, cross-sections, and terrain features.

From the 3D terrain model, DEM, DSM and orthomosaic it was possible to extract further features and profiles and export tiff files for additional processing and feature extraction in Trimble eCognition and ArcMap software.

\section{RESULTS AND DISCUSSION}

With use of sUASs, it is possible to acquire high-detailed information, with unmatched versatility and timing (Stark et al., 2013). In this study, the total covered area was 160 ha, in just over 3 hours of total flight time, between $10 \mathrm{AM}$ and $2 \mathrm{PM}$. The number of acquired images was 1,587. All images were in RGB .jpeg format.

All images were used to create a single terrain model in the photogrammetry software AgisoftMetashape. The initial processing took 2.5 hours. During this initial processing, dense point cloud (Picture 4), digital elevation model (Picture 2), digital surface model and orthomosaic (Picture 3) were produced.

The processing in Agisoft Metashape resulted in the creation of a dense point cloud with 147.2 $\mathrm{M}$ of points. The density of the point cloud allowed a precise spatial definition of fine terrain features which in turn resulted in the production of fine-detail DEM.

Distinguishing between features like vegetation, flat surfaces and bare 
surfaces, different levels of inclinations were easy due to the highly detailed point cloud and consequently DEM.

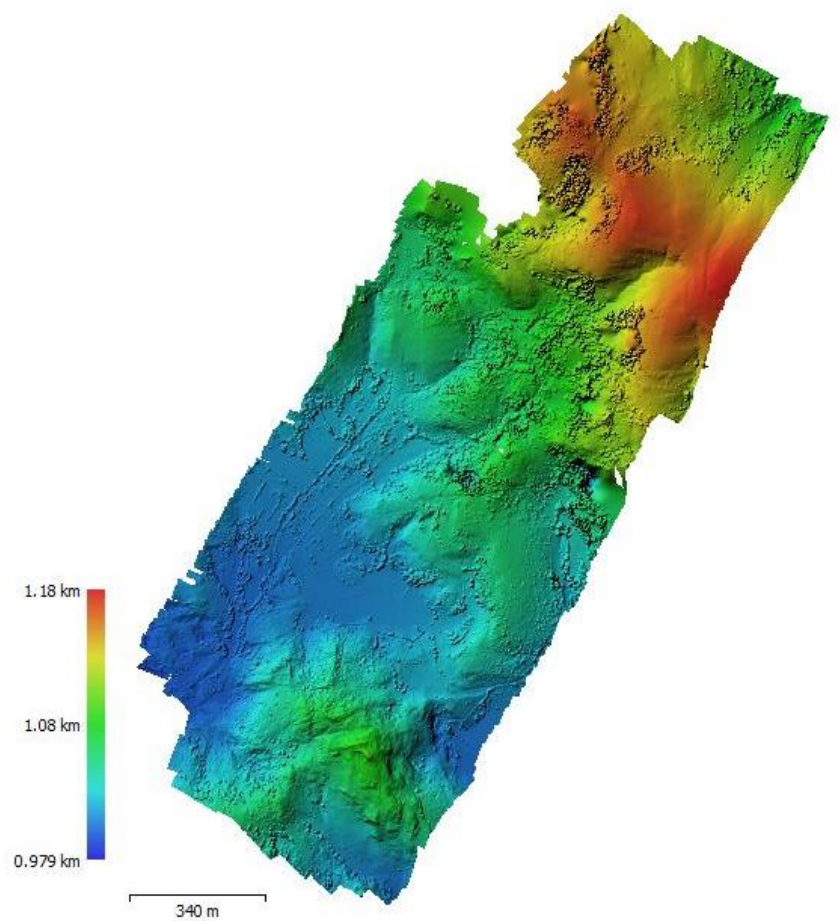

Picture 2. Digital Elevation Model with an elevation scale

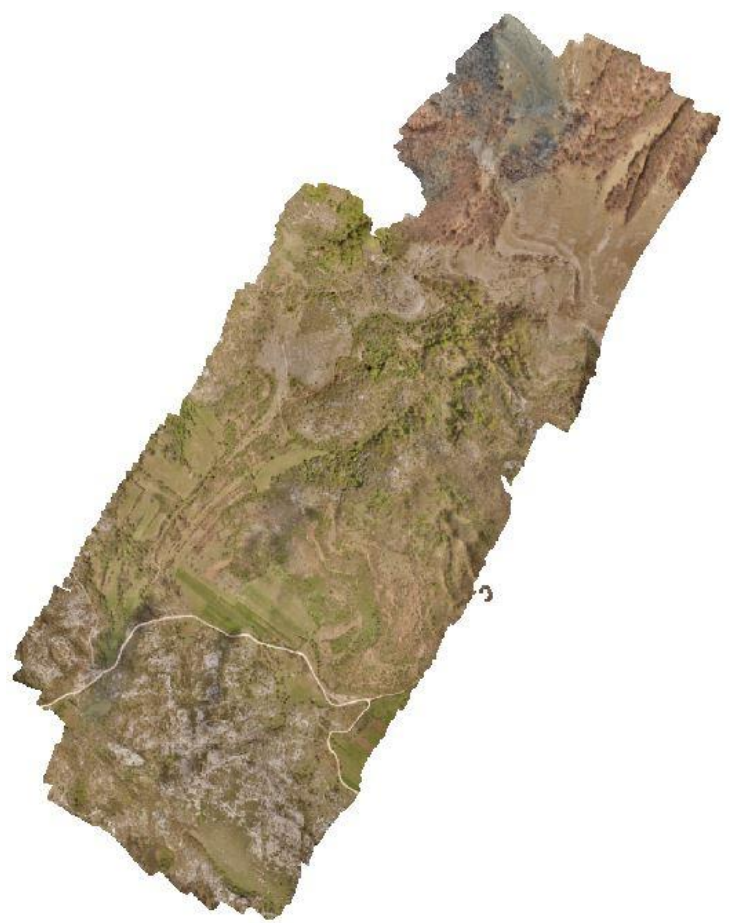

Picture 3. Orthomosaic 


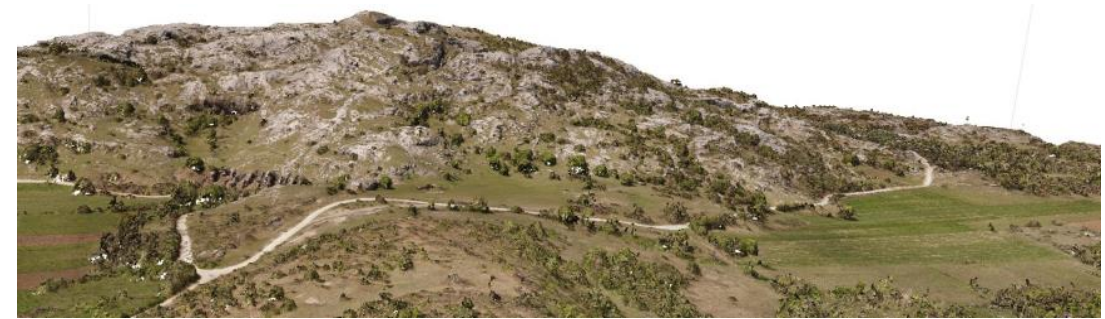

Picture 4. Main road and terrain view in Dense Point Cloud

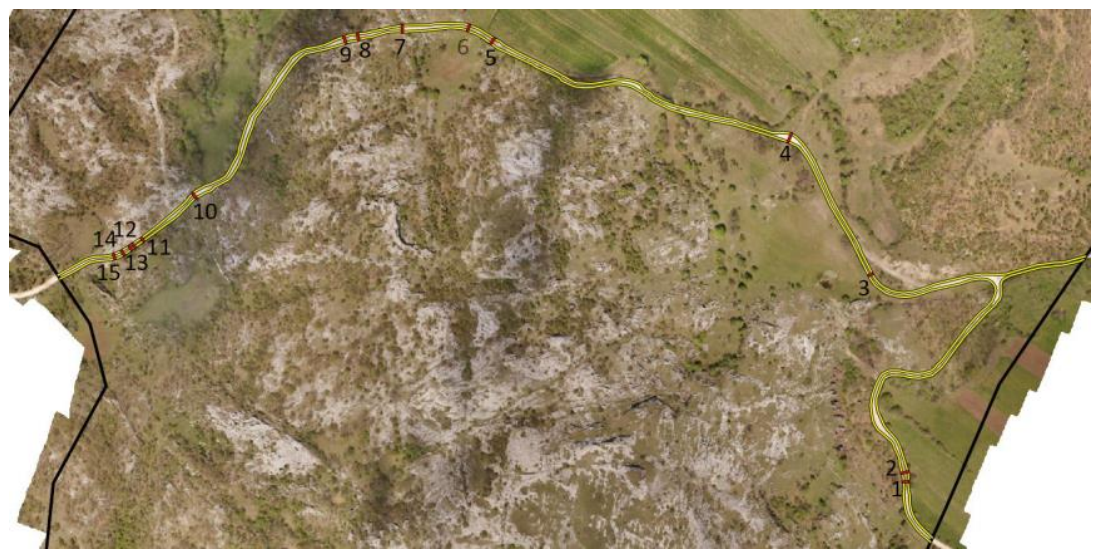

Picture 5. Main road-gravel road with position of profiles

The use of UAV primarily results in optimization of logistic processes, with the aim of reducing inventory costs, significantly shortening the process, reducing use of human resources (Škrinjar et al., 2018). This statement is confirmed with findings in this paper, but in addition to optimization of logistics process, possible advantages of use of sUAS in planning, work site monitoring and maintenance are also examined.

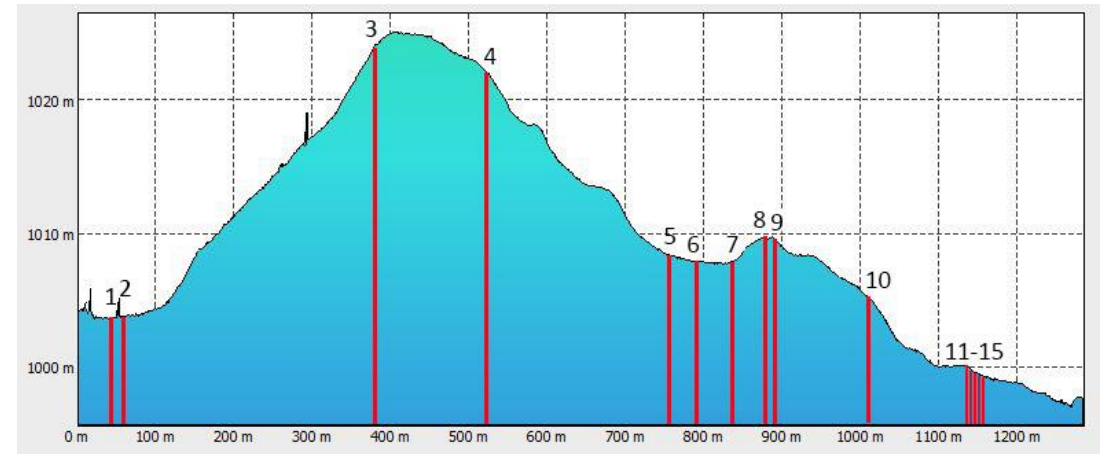

Picture 6. The longitudinal profile of the main road

The first thing examined was the main road which goes through the study area and as such is the main road for delivering personnel and equipment. The length of the road in this study area is $1,285 \mathrm{~m}$. It was also interesting to look into the state of the road. The most critical points of the road were identified (Picture 5). 
Table 1. Properties of the profiles

\begin{tabular}{|c|c|c|c|c|c|}
\hline Profile & $\begin{array}{c}\text { Distance } \\
(\mathbf{m})\end{array}$ & $\begin{array}{c}\text { Elevation } \\
(\mathbf{m})\end{array}$ & $\begin{array}{c}\text { Total width } \\
(\mathbf{m})\end{array}$ & $\begin{array}{c}\text { Damage width } \\
(\mathbf{m})\end{array}$ & $\begin{array}{c}\text { Percentage } \\
\text { of damage }\end{array}$ \\
\hline 1 & 53.32 & 1004.00 & 3.58 & 1.10 & 30 \\
\hline 2 & 60.89 & 1004.15 & 4.92 & 2.10 & 43 \\
\hline 3 & 391.36 & 1025.00 & 3.01 & 1.05 & 35 \\
\hline 4 & 521.21 & 1020.00 & 6.88 & N/A & 0 \\
\hline 5 & 777.82 & 1007.90 & 4.88 & 2.95 & 60 \\
\hline 6 & 799.84 & 1007.85 & 4.55 & 2.08 & 62 \\
\hline 7 & 853.16 & 1009.65 & 5.13 & 1.52 & 30 \\
\hline 8 & 889.32 & 1008.45 & 4.75 & 3.04 & 64 \\
\hline 9 & 900.22 & 1008.40 & 5.37 & 2.70 & 50 \\
\hline 10 & 1085.44 & 1000.10 & 4.28 & 1.44 & 37 \\
\hline 11 & 1140.18 & 999.10 & 2.80 & 2.14 & 76 \\
\hline 12 & 1148.71 & 999.08 & 3.13 & 0.98 & 31 \\
\hline 13 & 1152.04 & 999.05 & 3.30 & 0.73 & 22 \\
\hline 14 & 1159.21 & 999.02 & 3.48 & 0.93 & 27 \\
\hline 15 & 1166.73 & 998.85 & 3.60 & 1.70 & 47 \\
\hline
\end{tabular}

Fifteen profiles in total were identified on the main road, and that road was identified to be unpaved and covered with gravel and local materials from the surrounding decomposed rocks and stones. This type of road is not suitable for all vehicles, therefore this information about the type and health of the road should be considered when planning the field workflow.
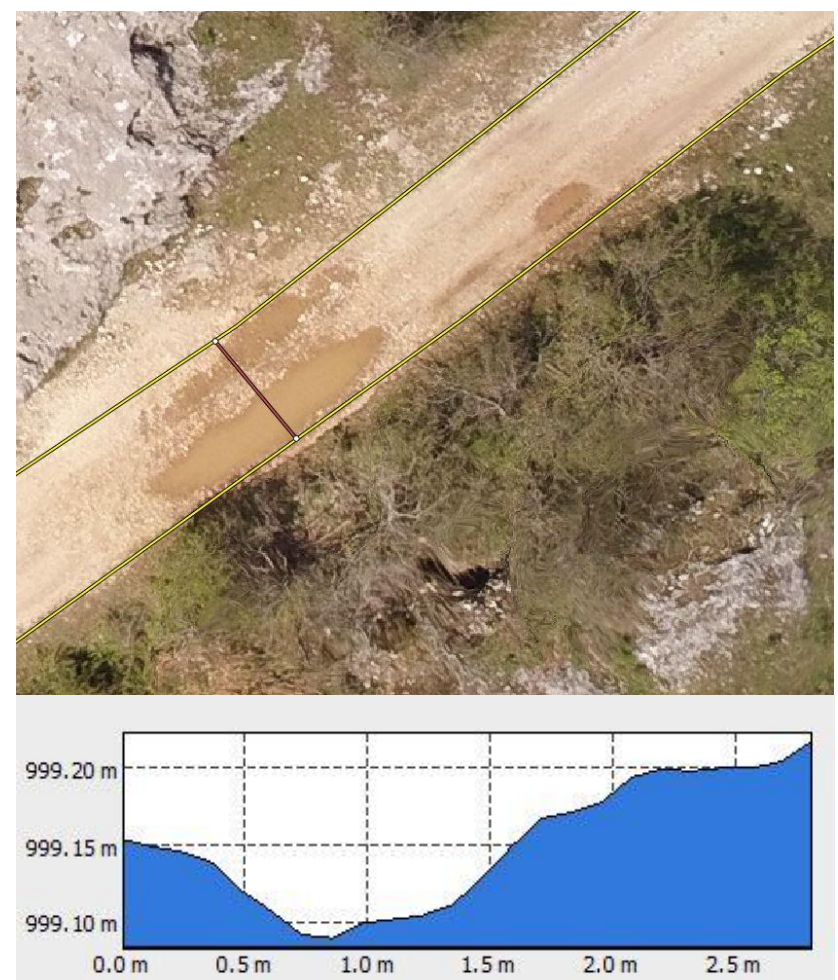

Picture 7. The minimum width of the road and its cross-section profile 


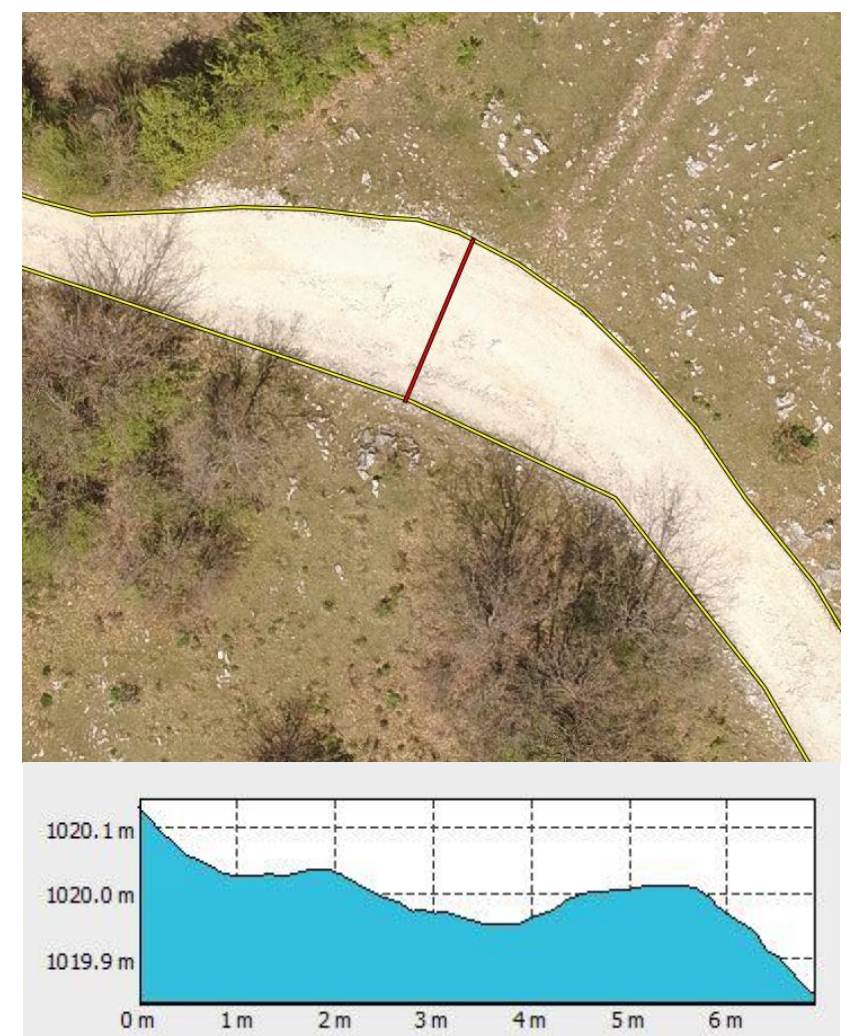

Picture 8. The maximum width of the road and its cross-section profile

Picture 6 shows the frequent changes of the slope, which in combination of the curvature of the road requires special attention during the transportation planning.

Extracted features were positions and profiles of the maximum/minimum widths and damages of the road. The properties of each selected profile of interest are presented in Table 1 .

From Table 1 it can be seen that Profile 11 has minimum width of $2.8 \mathrm{~m}$ and it has been identified at the distance of $1140.18 \mathrm{~m}$ from the beginning of the road in the study area. It is also where the road is the most damaged (76\%), which is clearly presented in Picture 7.

The profile with maximum width of $6.88 \mathrm{~m}$ is Profile 5 at the distance of $777.82 \mathrm{~m}$, and it has no visible damage (Picture 8).

Elevation changes in different parts of the terrain are well presented in the cross-section of the entire area (Picture 9). The main road, which is the most suitable for personnel and equipment delivery, is in the lowest part of the area. On both sides of the main road, the terrain rises abruptly, which can affect the further delivery of material, equipment, and human resources to the point of work.

In order to provide the information about the future work areas at different elevations, the thematic map of areas is shown in Picture 10.

The largest areas are found at the elevation between $1000 \mathrm{~m}$ and $1030 \mathrm{~m}$ above sea level. This area has the most potential for storing material, equipment 
and personnel, while the work is performed at higher elevation.

Many field works require precise knowledge about the aspect of the terrain for the efficient and the most successful workflow. Here is presented the thematic map of the terrain aspect of the entire study area (Picture 11).

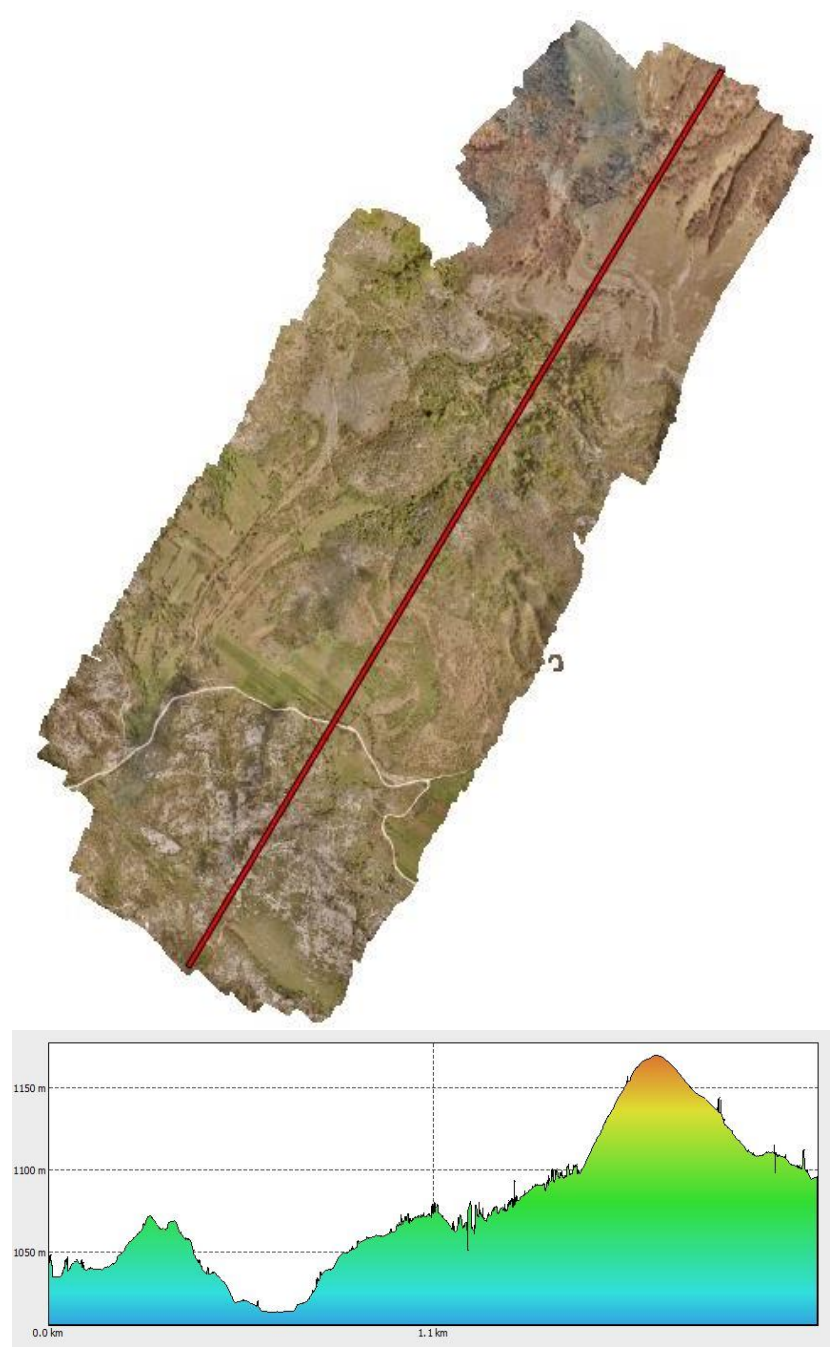

Picture 9. Cross-section of the entire study area

In Table 2 it is presented how much of the area every aspect occupies in percentage. The most dominant aspect is south-west.

The linear features of study area were extracted for better analysis of the terrain and in order to mark potential dirt road (Picture 12).

Picture 12 shows potential dirt road which utilizes the terrain features and current land use in the most appropriate manner and it is in accordance with them. This dirt road could prove to be the best way of delivery of materials, personnel, and equipment at the higher elevation of the study area.

Identification of existing and potential features in forested and hard to 
reach areas are of extreme importance in field work and environmental protection through biological monitoring and erosion protection.

Biological monitoring is defined as a system of collecting, assesing, and forecasting the changes in the environment caused by anthropogenic factors (Ratknić et al., 2013). One method of creation of soil erosion assesment maps is through collection and analyses, and comparison of existing land use maps and projects (Braunović et al., 2015). Through identification of landscape features very precise measurements and more accurate assesments of human impacts are also possible.

\begin{tabular}{|c|c|}
\hline \multicolumn{2}{|c|}{ Table 2. Aspect } \\
\hline Aspect & \% \\
\hline N & 9 \\
\hline NE & 11 \\
\hline E & 10 \\
\hline SE & 11 \\
\hline SE & 14 \\
\hline SW & 17 \\
\hline W & 15 \\
\hline NW & 12 \\
\hline Total & 100 \\
\hline
\end{tabular}

\section{Elevation Classification}

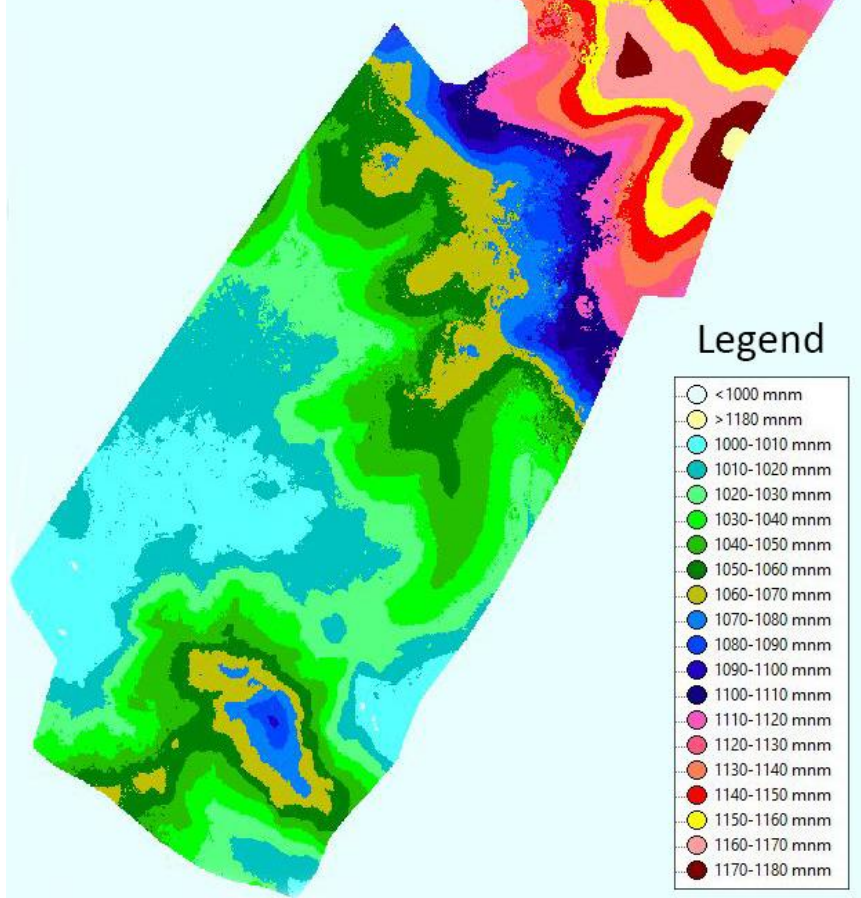

Picture 10. Classification of the terrain elevations $(10 \mathrm{~m})$ 


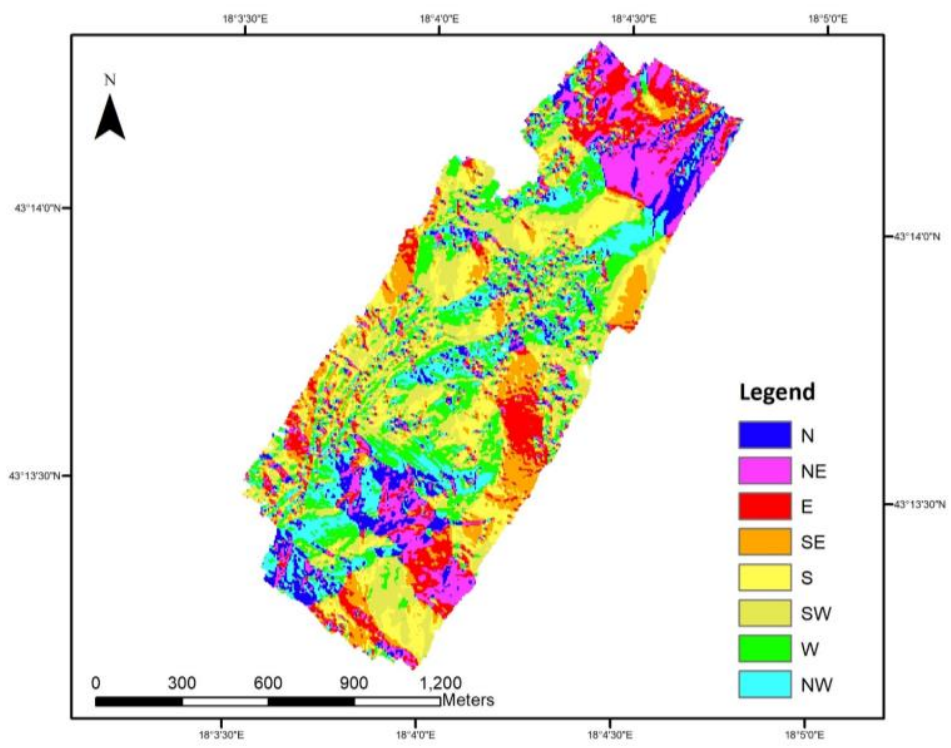

Picture 11. Terrain aspect of the study area

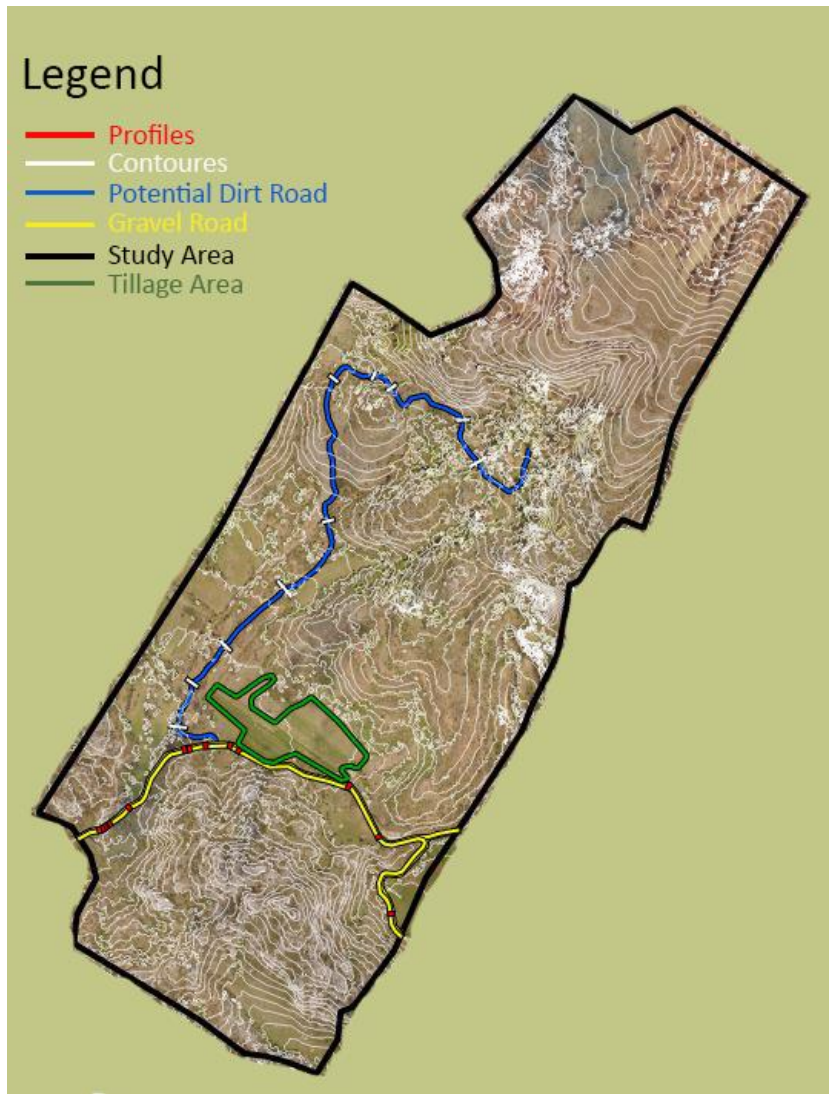

Picture 12. Extracted linear features of the study area 


\section{CONCLUSION}

Deployment of sUAS has numerous characteristics which make it suitable for mapping of hard-to-reach areas:

- it can be equipped with various imaging sensors;

- it is fast and easy to deploy;

- it exposes both user and the environment to the minimal risk;

- it can cover large areas in short time;

- its use comes at much lower prices than using traditional methods.

Using sUAS have decreased the possibility of human error to the minimum, so we can plan the work with original knowledge of the environment and get more information that can affect the workflow, and the outcome of the operations.

The raw data from the field can be easily stored in the digital form, and be revisited at any given time. This is especially important during the performance measurements and evaluation. In addition, it provides valuable asset for repeated processing of data, if any new technology would occur and compare the results of the current and future technologies.

Presented results and information can be used to improve the planning of the efficient workflow (cut costs and save time). However, these are just some of the information available from the use of sUAS. The amount and the sort of information ultimately depends on the types of the field work and the environment. There is also great potential in monitoring of the entire workflow and the qualitative and quantitative measurements of the performed work.

\section{REFERENCES}

Braunović, S., Ratknić, M., Ratknić, T., Kabiljo, M. (2015): Changes in land use in the region of Grdelica Gorge in the period 1963-2011, Sustainable Forestry, 71-72: 77-84

Campbell, J., Wynne, R. (2011): Introduction to remote sensing. The Guilford Press. New York

Ratknić, M., Ratknić, T., Miletić, Z., Čokeša, V., Stajić, S., Braunović, S., ĆirkovićMitrović, T. (2013): Changes of forest habitats destroyed by fire and the rate of natural revitalization of damaged ecosystems, Sustainable Forestry, 67-68: 117-132

Rodrigue, J., Comtois, C., Slack, B. (2017): The geography of transport systems. Routledge Taylor and Francis Group. New York

Stark, B., Smith, B., Chen, Y. Q. (2013): A guide for selecting small unmanned aerial systems for research-centric applications, IFAC Proceedings Volumes, 46(30): 38-45

Škrinjar, J., Skorput, P., Jakara, M. (2018): Application of unmanned aerial vehicles in logistic processes. 4th International Conference New Technologies NT-2018: Development and Application. June 14-16. Sarajevo. 359-366

(2004): https://www.ugpti.org/smartse/research/citations/downloads/Coifman- 
Surface_Transport_Surveillance_from_UAV-2004.pdf (accessed on 31. Oct. 2019)

(2015): http://gsp.humboldt.edu/olm_2015/courses/gsp_216_online/lesson2-2/air-

photos.html (accessed on 31. Oct. 2019)

\title{
APPLICATION OF SMALL UNAMANNED AERIAL SYSTEMS IN LOGISTICS AND PLANNING
}

\author{
Nenad ŠURJANAC, Natalija MOMIROVIĆ, Marija MILOSAVLJEVIĆ, \\ Sonja BRAUNOVIĆ, Milan KABILJO
}

\section{Summary}

Gathering the right amount of accurate data and information is crucial for proper and precise planning. Acquiring the field information of large and remote areas is timeconsuming. Due to the requirements of time and adequate personnel, the data gathering process is subjected to the various external and internal influences.

The application of small unmanned aerial systems significantly reduces the time needed for field data gathering. All acquired data are in digital format which makes them very suitable for automatic processing, information extraction, and sharing.

The quality and amount of extracted information allow much of the work and decision making to be done from the office without the need for multiple construction site revisiting.

This paper showed how quickly we can acquire raw data on 150 ha remote study area, and turn them into information needed for decision making. After spending a single day in a field, all available information regarding the identification of landscape, landcover, and existing and potential road profiles were extracted in the office. This approach saved time and provided information which is easy to read, share, process, and revisit if needed.

In this paper, it is represented how small unmanned aerial system, as a new technology for data gathering, is time effective and consequently cost-effective and represents a paradigm shift in the planning and monitoring of fieldwork.

Future application of systems like the one used in this paper will contribute to the acquiring of high-quality information which will further contribute to the management of projects.

\section{PRIMENA MALIH BESPILOTNIH SISTEMA U LOGISTICI I PLANIRANJU}

\author{
Nenad ŠURJANAC, Natalija MOMIROVIĆ, Marija MILOSAVLJEVIĆ, \\ Sonja BRAUNOVIĆ, Milan KABILJO
}

\section{Rezime}

Prikupljanje odgovarajuće količine podataka i informacija je ključno za precizno planiranje radova. Snimanje i sakupljanje podataka o velikim površinama, direktno na terenu, u nepristupačnim i udaljenim područjima zahteva mnogo vremena. Ako se uzmu u obzir zahtevi u vremenu i obučenom ljudstvu, moraju se uračunati i unutrašnji i spoljašnji faktori koji mogu uticati na kvalitet i količinu podataka koji se prikupljaju.

Primena malih bespilotnih sistema značajno smanjuje vreme potrebno za prikupljanje podataka. Svi sakupljeni podaci su u digitalnoj formi, što ih čini veoma pogodnim za automatsku obradu, dobijanje informacija, kao i deljenje i prosleđivanje.

Količina i kvalitet dobijenih informacija omogućavaju da sav posao i donošenje 
odluka prilikom planiranja budu završeni u kancelariji, bez potrebe za naknadnim terenskim radom.

Ovaj rad prikazao je koliko se brzo mogu prikupiti podaci o području velikom 150 ha i obraditi u korisne informacije. Sve informacije o pejzažu, topografiji, zemljišnom pokrivaču, poprečnim i podužnim presecima postojećih i potencijalnih puteva su dobijene u kancelariji. Ovaj pristup je uštedeo vreme i pružio informacije koje su lako čitljive, deljive i koje su dostupne za dodatnu obradu i naknadnu reviziju.

Ovim radom je demonstrirano da mali bespilotni sistemi, koji predstavljaju novu tehnologiju za prikupljaje podataka, štede vreme i novac i predstavljaju promenu načina na koji se donose odluke u planiranju i praćenju radova na terenu. Buduća upotreba ovakvih sistema će doprineti dobijanju kvalitetnih informacija koji će dalje doprineti upravljanju projektima. 